This study also has limitations. We could assess dementia status only among participants who were still members of the health plan when dementia was diagnosed. However, there were no differences in adiposity or sociodemographic characteristics in those who didn't continue in the health plan. Information on weight cycling, dieting, nutrition, or mid-life measures of cognitive functioning was not collected. A measure of central obesity, such as waist circumference was not collected. As diagnoses of dementia were made during medical visits, some cases of dementia may have been missed in those who did not participate in visits. This would bias results in an underestimation of the effects of obesity on dementia.

\section{Mechanisms of effects}

Adiposity is one component of the metabolic syndrome, which has also been shown to cause cognitive decline, particularly in those with high levels of inflammation. ${ }^{8}$ Perhaps adiposity has a direct effect on neuronal degradation. Genetically obese, leptin receptor deficient rodents have impaired performance on spatial memory tasks ${ }^{9}$ and long term potentiation of neurones in the hippocampus. ${ }^{10} \mathrm{C}$ reactive protein, an inflammatory marker, is increased in those with greater adiposity ${ }^{11}$ and is associated with dementia ${ }^{12}$ and cognitive decline. ${ }^{813}$ Recently, obesity in elderly women was shown to be associated with greater cerebral atrophy ${ }^{14}$ and white matter hyperintensity. ${ }^{15}$ Future studies of cytokines produced in fat cells and neuronal functioning should be useful.

Another study found that high skinfold thickness in mid-life was associated with Parkinson's disease. ${ }^{16}$ Perhaps adiposity works together with other risk factors to increase neurodegenerative disease.

Body mass index predicted dementia more strongly among women. These findings, however, are consistent with the only published prospective study on body mass index and dementia. ${ }^{3}$ There could be several reasons. There were fewer obese and overweight men, thus the power to detect an effect was reduced. Current body mass index categories may be insensitive indicators of adiposity in men because of less variation in the distribution of visceral fat. ${ }^{4}$ Perhaps body mass index and risk of dementia in women is mediated through central obesity, which is highly associated with insulin resistance, cardiovascular disease, increased adipocytokines, and inflammatory markers. All of these conditions could contribute to dementia. Diabetes and cardiovascular disease did not attenuate the effect, though the role of central obesity, inflammation, and adipocytokines on our findings is unknown and should be looked at in future research.

\section{Contributors: See bmj.com}

Funding: UCSF-Kaiser Building Interdisciplinary Research Careers in Women's Health Scholarship (5 K12AR47659) from the National Institutes of Health, Office of Women's Health. Competing interests: None declared.

Ethical approval: The study was approved by the internal review board of the Kaiser Permanente Medical Foundation.

1 Brookmeyer R, Gray S. Methods for projecting the incidence and prevalence of chronic diseases in aging populations: application to Alzheimer's disease. Stat Med 2000;19:1481-93.

2 Wang SY. Weight loss and metabolic changes in dementia.J Nutr Health Aging 2002;6:201-5.

3 Gustafson D, Rothenberg E, Blennow K, Steen B, Skoog I. An 18-year follow-up of overweight and risk of Alzheimer disease. Arch Intern Med 2003;163:1524-8.

\section{What is already known on this topic}

A recent study found that high body mass index in old age is associated with an increased risk of dementia in women, though body mass index is an insensitive measure of adiposity in elderly people and the subclinical phase of dementia causes weight loss

No studies have prospectively evaluated the effect of obesity in middle age on the subsequent risk of future dementia, and no studies have determined whether skinfold thickness is associated with dementia

\section{What this study adds}

People who were obese in mid-life were $74 \%$ more likely to have dementia, while overweight people were $35 \%$ more likely to have dementia compared with those with normal weight

Increased adiposity in the subscapular and tricep region in middle age was associated with a $60-70 \%$ increase in risk of dementia

These findings were not attenuated by presence of comorbid diseases in middle and late life

4 Baumgartner RN, Heymsfield SB, Roche AF. Human body composition and the epidemiology of chronic disease. Obes Res 1995;3:73-95.

5 Cronin-Stubbs D, Beckett LA, Scherr PA, Field TS, Chown MJ, Pilgrim DM, et al. Weight loss in people with Alzheimer's disease: a prospective population based analysis. BMJ 1997;314:178-9.

6 Knittweis J. Weight loss precedes Alzheimer's disease symptoms: a case study. J Am Geriatr Soc 1998;46:540-1.

7 Barrett-Connor E, Edelstein S, Corey-Bloom J, Wiederholt W. Weight loss precedes dementia in community-dwelling older adults. J Nutr Health Aging 1998;2:113-4.

8 Yaffe K, Kanaya A, Lindquist K, Simonsick EM, Harris T, Shorr RI, et al. The metabolic syndrome, inflammation, and risk of cognitive decline JAMA 2004;292:2237-42.

9 Funahashi H, Yada T, Suzuki R, Shioda S. Distribution, function, and properties of leptin receptors in the brain. Int Rev Cytol 2003;224:1-27.

10 Harvey J. Novel actions of leptin in the hippocampus. Ann Med 2003;35:197-206

11 Das UN. Is obesity an inflammatory condition? Nutrition 2001;17:953-66

12 Schmidt R, Schmidt H, Curb JD, Masaki K, White LR, Launer LJ Farly inflammation and dementia: a 25-year follow-up of the Honolulu-Asia inflammation and dementia: a 25-year foll

13 Yaffe K, Lindquist K, Penninx BW, Simonsick EM, Pahor M, Kritchevsky $\mathrm{S}$, et al. Inflammatory markers and cognition in well-functioning AfricanAmerican and white elders. Neurology 2003;61:76-80.

14 Gustafson D, Lissner L, Bengtsson C, Bjorkelund C, Skoog I. A 24-year follow-up of body mass index and cerebral atrophy. Neurology 2004;63:1876-81.

15 Gustafson DR, Steen B, Skoog I. Body mass index and white matter lesions in elderly women. An 18-year longitudinal study. Int Psychogeriatr 2004;16:327-36.

16 Abbott RD, Ross GW, White LR, Nelson JS, Masaki KH, Tanner CM, et al. Midlife adiposity and the future risk of Parkinson's disease. Neurology 2002;59:1051-7.

(Accepted 31 March 2005)

doi 10.1136/bmj.38446.466238.E0

\section{Endpiece}

\section{Too much or too little}

Old age is having too much room in the house and not enough in the medicine cabinet.

Robert Orben, American humorist

Fred Charatan, retired geriatric physician, Florida 